\title{
Reconstruction of the Purposes and Guidelines of Sentencing in Indonesian Sentencing System Based on the Perspective of Human Rights and Pancasila
}

\author{
Zakky Ikhsan Samad \\ Faculty of Law \\ University of Lampung \\ Lampung, Indonesia \\ zakkysamad@gmail.com
}

\author{
Munandar \\ Faculty of Law \\ University of Lampung \\ Lampung, Indonesia \\ m.nandar685@gmail.com
}

\author{
Wahyu Noviarini \\ Faculty of Law \\ University of Lampung \\ Lampung, Indonesia \\ wnoviarini@gmail.com
}

\begin{abstract}
Development in the field of law one of which is based on providing guarantees for the protection of human rights, which is mainly implemented based on the values that exist in Pancasila. Whereas in relation to the development and evolution of criminal law, one of the important issues that has often been debated, and the problem both in terms of normative order and practice is regarding the purposes and guidelines of sentencing, especially with regard to guaranteeing the protection of human rights for the subjects involved in it. Therefore, the authors are interested in reconstructing the purposes and guidelines of sentencing in the sentencing system in Indonesia based on the perspective of Pancasila, and then looking for the ideal form of conception of the purposes and guidelines of sentencing later. Based on the author's study it is known that the current purposes and guidelines of sentencing are not generally accommodated in the provisions of material law, formal law, and implementation rules. It causes criminal law enfocement in normative way losing its soul/spirit and "taste" while implementing its sentencing system, as well not fully provided real protection for the rights of the suspect / defendant / convicted, victim or the wider communit. Therefore, a reconstruction of the existence of the purposes and guidelines of sentencing in the Indonesian legal system is needed, by adjusting it to the development of sentencing theory, strengthening of human rights protection, and the main values of the Indonesian people which is contained in Pancasila. Whereas in formulating the purposes and ideal guidelines of sentencing, it must be based on the idea of balance which is obtained from the development of sentencing theory by adjusting it to the aspects of human rights protection, and characteristics of Pancasila as the main basis for the development.
\end{abstract}

Keywords-Reconstruction, Purpose and Guidelines of Sentencing, Sentencing System, human rights, Pancasila.

\section{INTRODUCTION}

Pancasila for the Indonesian people is a core philosophy so that it is a local genius and local wisdom of the Indonesian nation so that its position can be said to be a ground norm or basic norm [1]. Pancasila as the nation's view of life consists of a series of noble values which are a comprehensive insight into life itself. As a way of life, Pancasila serves as a frame of reference for managing personal life as well as in interactions between humans in society and the natural surroundings. In addition, Pancasila serves as a guide and direction for the Indonesian people in all activities and activities of life and life in all fields.

Whereas in the development of national law, a guideline is needed so that the development of the law can support the achievement of national goals. The reform of the Indonesian National Law System that has been intended to be realized is the Pancasila-based National Law System. This is in line as stated by Sudarto, who said that the Indonesian state in carrying out its legal politics is based on the basic philosophy of the State, namely Pancasila and the 1945 Constitution. Development in the field of judicial power is also inseparable from the values contained in Pancasila. Pancasila as the basis and the ideology of the state is at the same time the source of all sources of law in Indonesia. Therefore, there should be no laws and regulations in force in Indonesia that contradict Pancasila. However, Pancasila as the basis of the state must be able to adapt to the objective conditions of modern Indonesian society [3].

Law is a tool or vehicle to organizing state life or order and organize social welfare. Therefore, the law as a tool must be able to be built, shaped, and applied under the basic values of the Indonesian nation as 
crystallized in Pancasila [4]. One of the functions of Pancasila itself can be understood as a building of thought that directs the law to the ideals aspired by the Indonesian people, as stated by Attamimi, Pancasila as a legal ideal (rechtsidee) will perform two functions which are constitutive and regulatory against the system of Indonesian legal norms. consistently and continuously. As a legal ideal (rechtsidee), Pancasila has three values, namely basic values, instrumental values, and practical values. These three values are later concretized into legal norms or rules. The concretization of these three values is very important because the law as a tool must be able to integrate and harmonize Indonesia's national interests broadly and comprehensively [5].

Whereas concerning development, and the development of criminal law from the past to the present, one of the important issues that are often debated, both in the normative order and in practice, is regarding the objectives and guidelines for sentencing, especially concerning the certainty or guarantee of the protection of human rights. human rights (hereinafter referred to as "HAM") in the process (whether including perpetrators of criminal acts, victims, and other related parties). As is well known, in Indonesia's current national material law system, namely the Criminal Code (hereinafter referred to as "KUHP"), it is not possible to find out what is the purpose of sentencing, and how to guide the punishment. However, the aim and these sentencing guidelines are very important to provide a "taste or taste" in the running of the sentencing system or criminal law enforcement system. This becomes relevant when juxtaposed with the function of law as a tool, and Pancasila as a legal ideal, where of course this tool if it is not built, filled, and applied by basing it on the values of Pancasila then the law will only become a merely written norm whose application is cannot guarantee the achievement of national and state goals that can protect all its citizens. In addition, the context of guaranteeing the protection of human rights carried out by the state in a sentencing system is also very important, because the main stakeholder of human rights obligations is the state [6].

That by not including the purpose and guidelines for punishment, in the end, the sentencing system or criminal law enforcement system becomes rigid/formalistic, ignores the ideals and functions of the essential law, results in multiple interpretations of its application, and results in abuse of authority which can have an impact on human rights violations for the parties involved in it. The occurrence of this is natural because the purpose of this punishment is an important element in the sentencing system or criminal law enforcement, where the purpose of this punishment is to act as a soul/spirit that gives "taste and taste" in the implementation of the system so that it is not only carried out formally, while this sentencing guideline is needed as a guide, and as a basis used in guidelines for imposing a sentence or achieving the purpose of the sentencing so that it is right on target.

Based on the background of the problems, and the conditions mentioned above, the author is interested in examining this in more depth by raising this issue in this article with the title "Reconstruction of the Purpose and Guidelines for Criminalization in the Indonesian sentencing system Based on the Perspective of Human Rights and Pancasila".

\section{PROBLEMS}

1. Is it necessary to reconstruct, and renew the objectives, and guidelines for punishment in the Indonesian sentencing system based on the perspective of human rights and Pancasila?

2. What is the ideal conception of the goals and guidelines for punishment in the Indonesian sentencing system in the future?

\section{RESEARCH METHOD}

This research is normative juridical. There will be three approaches to the problem, namely, the statutory approach, the historical approach, and the analytical approach. Data collection in this writing is done by a literature study. The existing data is processed by steps, data selection, data classification, and data systematization. The data to be obtained is then analyzed using a normative-qualitative model or approach. Next, the results were written using the descriptive-analytical method. Conclusions are drawn using inductive logic.

\section{RESUlT AND DISCUSSION}

A. Reconstruction of Goals and Guidelines for Criminalization in the sentencing system in Indonesia Based on the Perspective of Human Rights and Pancasila

The history of sentencing regarding criminal forms in many countries has undergone changes and progress, especially in terms of humanity, this is as reflected in the development of three main groups of theories to justify the imposition of a crime, namely [7]: 1) absolute/retributive/vengeance theory (vergeldings theory), where according to the theory of retribution (retribution theory) [8], the justification for imposing a sentence is sole as a reward for the evil act committed by the perpetrator [9]; 2) the relative theory or utilitarian theory, which according to this theory punishing is not a means to include the absolute demands of justice [10], crime does not have to be punished but there must be benefits both for the perpetrator of the crime and for the community [11], This theory puts more emphasis on the aspect/side of prevention, the purpose of the crime is to protect the community or eradicate crime, this theory tries to find a justification for a crime solely on one particular purpose, which is then divided into two types of theories, namely general prevention theory [12], and 
special prevention theory [13]; 3) integrative/combined theory [14], where this theory is a combined theory between absolute theory and relative theory, The basic idea of this combined theory is in the way of thinking that the crime should be a combination of goals for retaliation and community protection which is applied in combination according to the crime committed and the circumstances of the maker [15].

The development of these theories of punishment is basically in line with the development of strengthening guarantees for the protection of human rights that are developing throughout the world, where the direction of development of these theories of punishment is essentially adopting, and making the protection of human rights (both for the perpetrators, victims, and the community) one of the main reasons for the need for a change to the paradigm of existing criminal theories. Therefore, the direction and purpose of the punishment of a provision will be greatly influenced by the understanding and application of the theory of punishment that it wants to achieve.

Indonesia itself, as stated by Muladi [16], adheres to, and justifies three main groups of theories to justify the imposition of a criminal, so that the whole theory of punishment is implemented in the set of sentencing objectives. The purpose of this punishment is generally contained in the provisions of material criminal law, which then technically or the way of its realization can be re-arranged, and confirmed in formal legal provisions and criminal implementing provisions. However, in Indonesia, the purpose of this punishment cannot be found in our main national material criminal law system currently in effect, namely the Criminal Code, nor the Criminal Procedure Code (hereinafter referred to as "KUHAP"), and only has a goal at the stage of implementing the act number 12 of 1995 concerning the Correctional System (based on this provision the implementation of the criminal deprivation of liberty is carried out using the model of the correctional system).

This of course will be irrelevant, because the purpose of this punishment is the basis and guidance in achieving the successful implementation of the sentencing system or criminal law enforcement system by a country. However, in Indonesia, in general, the purpose of punishment seems to be still limited to theoretical aspects and is purely abstract, where the purpose of punishment has been recognized, but its implementation is still in the study of the theoretical realm in the order of philosophical and sociological aspects of the sentencing system or enforcement system. criminal law alone, without a normative (written) juridical affirmation to be used as the main basis for law enforcement officials, judges, and other related parties within the framework of the criminal system or criminal law enforcement process in Indonesia.
This problem is since the Criminal Code as a general material criminal law that applies in Indonesia does not formulate all the general conceptions contained in the teachings of criminal law concretely in its regulation, such as the one regarding the provisions of the objectives and guidelines for sentencing. The purpose of this punishment is the soul/spirit of an applicable criminal law provision so that the absence of this sentencing purpose will result in a legal provision that will lose its essence and "taste" in it, because this system will run rigidly, formally, has no purpose in it, and tends to ignore the protection of human rights for the parties involved in it (perpetrators, victims, and the community). This of course will be not good in its application, where even though the purpose of punishment has been normatively taught, and is known to be a philosophical basis in an imposition of punishment based on the values of Pancasila which includes guarantees for the protection of human rights in it, but in the absence of a concrete form in writing against the purpose of sentencing in material criminal provisions, then this will lead to obstacles, such as doubts regarding the interpretation of the intended form of punishment, abuse of power, discrimination in law enforcement (using the reason for the purpose of sentencing as a means of "selecting cases" on subjective interests), and/or ignoring the purpose of punishment itself on the grounds that it is not a norm or mandatory provision that must be fulfilled, as well as other negative impacts that can occur.

According to the experience and observations of the author as one of the subjects who run this sentencing system or criminal law enforcement system, the purpose of punishment in practice is sometimes difficult to implement, and often even neglected, happens because by not including the purpose of punishment in the form of written legal rules, be it in material law, formal, and the implementation of criminal law, often the sentencing system or the criminal law enforcement process is only carried out formally and rigidly. Law enforcement officials, judges, and other law enforcement elements who are in the criminal justice system or criminal law enforcement are often just a mere mouthpiece of the law, ignoring aspects of justice and expediency, human rights protection has not been fully implemented properly, and the purpose of punishment is not the main thing in running the system.

This problem mainly occurs due to the absence of regulations and guidelines that clearly state how the form, and concrete form of the purpose of punishment to be achieved in the implementation of the sentencing system or criminal law enforcement system in Indonesia today. Therefore, in practice, law enforcement is often only legalistic, although there are still many criminal law enforcements carried out by seeking and understanding fundamentally the understanding of the purpose of punishment. However, although in practice there are still quite a lot of law 
enforcers, judges, and other officials who are wise in understanding the philosophy of the purpose of punishment as well as the development of the goals of the applicable punishment, or dare to go out of the box to get out of mere formalistic provisions by looking for a basic aspect of justice, even though the existing rules are rigid and seem impossible, of course, that does not mean that there are no consequences, where those who dare to interpret the provisions they feel are not fair or rigid, by thinking out of the box will always be faced with aspects that violate existing normative provisions. If the purpose of this punishment is concreted in writing, and its position is placed as the soul/spirit of the sentencing system, then this can certainly be a basis or main foothold for law enforcers, judges, and other apparatuses to overcome legal provisions which are often legal rigid and formalistic.

Whereas apart from not being accommodated regarding the form of objectives, and the written guidelines for sentencing, the policy formulation of the Criminal Code in Indonesia is still derived from the legacy of the Dutch colony, whose formulation still tends to be oriented towards mere criminals, whose philosophy at that time was based on individualism and liberalism [17]. Therefore, on that basis, a reconstruction (rearrangement) and renewal of the objectives, and guidelines for this sentencing in the future is needed to accommodate, and replace the policy form of the formulation of the Indonesian Criminal Code which is still thick with classical/neoclassical schools, which of course is not in line with the spirit of the Indonesian Criminal Code. the development of the theory of punishment in Indonesia, and the main values of the Indonesian nation as embodied in Pancasila, as well as the spirit of strengthening the protection of human rights.

Given the importance of goals and guidelines for punishment in this sentencing system, reconstruction or rearrangement, and renewal of its conceptions must be carried out by aligning them with the values of Pancasila (as the philosophy of the state, and at the same time as ideals and sources of law (rechsidee), and strengthening the protection of human rights for all parties involved in it. Pancasila as the philosophy and ideology of the Indonesian nation and state shows the values contained in Pancasila are derived from the Indonesian people themselves, namely the values of customs, culture, and religious values, while guaranteeing the protection of human rights are basic values / values. essential that must be contained, and its fulfillment is guaranteed by the state. Therefore, Pancasila, and guarantees for the protection of human rights should have an imperative nature, that is, they must be used as the basis, and the main development direction for the national legal philosophy, as well as a reference in the preparation, development and development of a legal philosophy that is consistent and relevant to the values contained [2].
As a legal ideal (rechsidee), both Pancasila and the guarantee of human rights protection essentially have three values, namely basic values, instrumental values, and practical values. These three values are later concretized into legal norms or rules. The concretization of these three values is very important because the law as a tool must be able to integrate and harmonize Indonesia's national interests broadly, and comprehensively so that these Pancasila values are used as guiding stars to test and provide direction for positive law in Indonesia [5].

Therefore, with Pancasila, and the guarantee of the protection of human rights as legal ideals, both are normatively the source or basis of all sources of law. Pancasila as the source of all sources of law has been regulated for a long time, and its existence is recognized in the hierarchy of Indonesian national laws and regulations, where this is as among others legally legitimized through TAP MPR Number XX/MPRS/1966 concerning the DPR-GR Memorandum regarding Orderly Sources. The Law of the Republic of Indonesia and the Order of the Legislative Regulations of the Republic of Indonesia, and then after the reform the existence of Pancasila was reaffirmed in Law Number 10 of 2004 which was later replaced by Law Number 12 of 2011 concerning Legislation [18], while the protection of human rights itself, apart from the main provisions in force, is highly recognized and upheld in the international world, it is also the main mandate and ideals that must be realized and carried out as mandated by the constitution of the Republic of Indonesia.

Based on the above, all laws and regulations policies, one of which is related to the form of objectives, and sentencing guidelines as the main focus in the discussion of this paper must be reconstructed (rearranged) and updated by adjusting, and aligning them with the values that contained in Pancasila both as the basis/ideology of the state as well as the ideals and sources of the law itself, one of which is by upholding and strengthening the protection of human rights in it. Pancasila as the source of all these sources of law must essentially mean that the entire national legal system must be based on Pancasila, as well as guarantees for strengthening the protection of human rights which must also be included and understood essentially in its embodiment. Therefore, as an embodiment of the reconstruction (rearrangement) efforts, and the renewal of the goals and guidelines for the current sentencing, it is necessary to reform the formulation of policies (formulations) on the Indonesian national legal system, whether it is carried out on material, formal, and legal laws. implementing the crime, by incorporating the values of Pancasila, and guaranteeing the protection of human rights as the philosophical basis for its manufacture. 


\section{B. Ideal Conception of Goals and Guidelines for Criminalization in the Criminal System in Indonesia}

The development of the approach to the purpose of punishment, starting from absolute/retributive/retaliation theory, relative theory of utilitarian theory, and integrative/combined theory [19], which has now been echoed by the theory of punishment concerning obtaining restorative justice [20]. as if it has not been fully interpreted, this is because the approach regarding the applicability of the purpose of sentencing which is aspired by law in Indonesia is based on the values of Pancasila, and the strengthening of human rights protection in general, apart from not being fully imbued with, also does not have a normative basis for legal provisions that are (specifically, this aspect of the purpose of sentencing to achieve restorative justice has existed, since the enactment of Law Number 11 of 2012 concerning the Juvenile Criminal Justice System). The Criminal Code, and the Criminal Procedure Code as embodiments of general material and formal law in Indonesia, have not explicitly stated what is the purpose of punishment [21], The purpose of the punishment should ideally be the same and in harmony with the entire series of criminal systems or criminal law enforcement systems and must be oriented and consider thoroughly both in terms of the interests of the perpetrators, victims, society, and the state.

Whereas as described in the previous discussion, by not formulating the objectives and guidelines for punishment in the provisions of material law, formal law, and the rules for its implementation, normative criminal law enforcement seems to have lost its soul/spirit, where the material law provisions often become rigid in their application. by only considering from the side of the perpetrator alone, which results in the imposition of the punishment also tends to be only numerical or only considers the quantity alone, without being based on the ratio or quality reasons behind the imposition of the number or the crime. Whereas in practice, the criminal law enforcement process often becomes merely formalistic, by only prioritizing the fulfillment of elements of the existing material law, where law enforcers tend to be worried when implementing or doing what they think should be done to achieve justice for all parties, but because the basic instrument as a basis or orientation in sentencing is not explicitly regulated, the enforcement process and the imposition of a crime tend to be rigid and formalistic. Likewise with the implementation of the crime, where the concept of correctional must also be adjusted and developed by following the purpose of the sentence. and the imposition of a crime tends to be rigid and formalistic. Likewise with the implementation of the crime, where the concept of correctional must also be adjusted and developed by following the purpose of the sentence. and the imposition of a crime tends to be rigid and formalistic. Likewise with the implementation of the crime, where the concept of correctional must also be adjusted and developed by following the purpose of the sentence.

Therefore, the function and purpose of punishment are very important to be concreted and strictly regulated both in material law, formal law, and the law of implementation. This is important so that there is harmony or understanding for all implementing elements integrated into the criminal law enforcement system or criminal law enforcement, where the purpose of future punishment is essentially preventing the occurrence of criminal acts by enforcing legal norms, socializing the perpetrators of criminal acts by providing guidance, resolve conflicts caused by criminal acts, restore balance, and bring a sense of peace in society, as well freeing the guilt the perpetrators of the crime [22].

That is the development of the latest RKUHP [28], has been regulated and compiled regarding the purpose of sentencing, and guidelines for sentencing [23].

The purpose of punishment as regulated in the provisions of Article 52 of the RKUHP states:

"(1) Sentencing aims at a. prevent the commission of criminal acts by enforcing legal norms for the protection and protection of the community, $b$. socialize the convicts by conducting coaching and mentoring so that they become good and useful people, c. resolve conflicts caused by criminal acts, restore balance, and bring a sense of security and peace in society, and d. cultivate a sense of remorse and release the guilt of the convict; (2) Sentencing is not intended to degrade human dignity." [24].

Based on this, the orientation or approach to punishment is based on several things, namely prevention of criminal acts, correctionalization of convicts, resolution of conflicts due to criminal acts, and liberation of guilt in convicts, which is then followed by guarantees for human dignity.

In connection with the concept of the purpose of punishment as regulated in this RKUHP, Sudarto put forward the meanings of each of the goals of punishment, namely in the aspect of preventing criminal acts aimed at protecting the community (social defense) and general prevention, in the aspect of penalizing the convicts aiming for the rehabilitation and resocialization of convicts (special prevention), in the aspect of resolving conflicts due to crimes related to the view of customary law (reactive costum) which aims to restore balance, and in the aspect of releasing the guilt of the convict it aims at spiritual values such as the First Precepts of Pancasila [25]. Based on this, the purpose of sentencing in this RKUHP will generally show that the theory of punishment that we adhere to is utilitarian because the purpose of this punishment describes that this punishment must be prospective or forward-looking, accompanied by preventive/preventive efforts with the ultimate goal of 
social welfare. social welfare). In addition, from the formulation of the purpose of punishment, it is clear that there is a balance between public/community protection and individual protection which is embodied by the concept is the implementation of the "idea of balance with the basis of Pancasila as the main foundation of its value.

That the formulation of the purpose of sentencing as above is in essence very good to be applied, this is none other than because the thoughts, discussions, and formulations regarding the purpose of sentencing must have been carried out comprehensively by involving legal experts, and other relevant parties who have competence. However, according to the author, the purpose of the sentencing can still be improved or added by inserting the values that exist in restorative justice, the values contained in other Pancasila, and aspects of strengthening the protection of human rights for the better. The addition of Pancasila values, here means that it is adjusted to the values of the religious moral paradigm, humanity (humanist), nationality, democracy, and social justice.

The addition of the values contained in the purpose of punishment as stated in the RKUHP according to the author would be more ideal if it became the five main points of the purpose of punishment as follows:

- First, namely adding the aspect of "justice" in the purpose of the first sentencing, so that it reads as follows: "Preventing criminal acts by enforcing legal norms, and justice for the protection and protection of the community". This editorial addition, and the meaning of justice enforcement, according to the author, is important, so that the purpose of crime prevention in this aspect is not only seen as an aspect of written legal norms, so that it can make its application back to being formalistic and rigid, but must also be interpreted with broad values of justice, and comprehensive, so that there is an idea of balance in it;

- Second, namely changing the structure of the second sentencing objective by adding a new sentencing objective which reads "To provide a sense of justice, legal certainty, and benefit to victims, perpetrators, the community, families of victims and/or perpetrators, and the state/government." The addition of the purpose of punishment is carried out so that the purpose of punishment can provide the fulfillment of the idea of a balance of aspects of justice, legal certainty, and benefit for all parties so that whatever form of punishment that will be imposed later is expected to be carried out after going through a struggle against the values and existing conditions. such;

- Third, namely still by placing the third sentencing goal in the form of "Resolving conflicts caused by criminal acts, restoring balance, and bringing a sense of security and peace in society." The goal in the form of resolving this conflict must be placed in the third place or before the purpose of sentencing in the form of socializing the convict, because it is expected, and efforts to resolve the conflict must have begun to be applied both in the preadjudication, adjudication, until finally the postadjudication stage, things are needed to achieve recovery the balance of the conditions caused by the crime can be achieved as quickly as possible, to minimize protracted conflicts, especially against criminal acts whose victims are fellow members of the general public.

- Fourth, namely putting the second sentencing objective into the fourth by improving the editorial, and the substance becomes "Socializing criminal offenders by providing guidance, and mentoring to become good and useful people." This change in the composition of the objectives of sentencing is intended to make this series of sentencing objectives systematic, where after seeing the success or failure of efforts to achieve conflict resolution with efforts to restore balance, the next point is to re-populate the convict if he is sentenced to prison on thorough consideration of the previous sentencing objectives, which is carried out using a model of coaching and mentoring so that after the convict has finished serving his prison term, he will be able to,

- Fifth, namely by adding an editorial, and the meaning of the purpose of sentencing the four RKUHP, so that it reads "Growing a sense of regret for the criminal acts committed, and freeing the guilt of criminal offenders by instilling the noble values of the Indonesian nation". This addition of course is not interpreted merely editorially, but must be interpreted really as a manifestation of the ultimate/final sentencing goal by fostering a feeling of trying to regret in the context of the criminal act so that he will never return to committing a criminal act because it is hoped that after the convict is carrying out punishment by using the penitentiary system by instilling the noble values of the Indonesian nation which are generally as crystallized from the values contained in Pancasila.

Whereas based on the above, basically the concept of the purpose of punishment above is a combined concept of the protection of human rights both for the perpetrator, the victim, the family of the perpetrator/victim, the general public, and the state/government by using the idea of balance that is harmonized with the development of the purpose of punishment. which is based on the characteristics of 
the values of Pancasila as the main basis for the development of legal characteristics in Indonesia which include the values of the religious moral paradigm, humanity (humanist), nationality, democracy (populist/people wisdom), and social justice.

In addition to the regulation of the aims of punishment, it is also necessary to regulate the guidelines of sentencing in concrete or written form. This is important because these sentencing guidelines are also an integral part of the criminal sub-system or criminal law enforcement system (as is the case for the sentencing system ), where it is this sentencing guideline that will act as a means of control or control over the implementation of criminal convictions, in addition to the sentencing guidelines. This is also necessary so that there is a philosophical foundation that is concrete in the imposition of sentencing so that in carrying out this sentencing system it can run under the context and corridors of the expected sentencing objectives.

Whereas in the current development of the latest RKUHP, sentencing guidelines are regulated and contained in the provisions of Articles 53, and 54 of the RKUHP, which state as follows:

"Article 53: (1) In adjudicating a criminal case, the judge is obliged to uphold law and justice. (2) If in upholding law and justice as referred to in paragraph (1) there is a conflict between legal certainty and justice, the judge is obliged to prioritize justice; Article 54: (1) In sentencing, it is mandatory to consider: a. the guilt of the perpetrator of the Crime; $b$. the motive and purpose of committing the Crime; $c$. the inner attitude of the perpetrator of the crime; $d$. Crime is committed with a planned or unplanned; e. how to commit a Crime; f. the attitude and actions of the perpetrator after committing the crime; g. curriculum vitae, social condition, and economic condition of the perpetrator of the crime; $h$. criminal influence on the future of the perpetrators of the crime; i. the influence of the Crime on the Victim or the Victim's family; $j$. forgiveness from the Victim and/or his family; and/or k. values of law and justice that live in society. (2) The lightness of the act, the personal condition of the perpetrator, or the circumstances at the time the crime was committed and what happened afterward can be used as a basis for consideration not to impose a crime or not to impose an action taking into account the aspects of justice and humanity." [26].

Whereas based on the above, it is known that the punishment guidelines in the RKUHP actually contain things that are the basis or basis for the criminal process, but if one looks closely, the sentencing guidelines regulated in the RKUHP still tend or are dominantly filled with juridical/legal aspects. mere, and its application seems to be only at the stage of adjudication which is intended for judges in the process of imposing their crimes. This sentencing system must also consider other non-legal aspects in a balanced manner because in the sentencing system legal aspects cannot stand alone but are influenced by other nonlegal aspects (such as philosophical aspects, sociological aspects, psychological aspects, etc.). cultural aspects, economic aspects, and aspects of the balance of interests for the perpetrators of criminal acts, victims of crime, families of perpetrators and/or victims, society, and the state), which are then applied in each stage (pre-adjudication, adjudication, and afteradjudication) as a unified sentencing system or enforcement system. criminal law. These non-legal aspects become very important to consider and are included in the sentencing guidelines, because the purpose of this punishment is a combination of objectives between legal and non-legal aspects, which is nothing but the implementation of the values of Pancasila as the source of all laws, and legal ideals to be achieved in the sentencing system or criminal law enforcement system. which is then applied at each stage (pre-adjudication, adjudication, and postadjudication) as a unified sentencing system or criminal law enforcement system. These non-legal aspects become very important to consider and are included in the sentencing guidelines, because the purpose of this punishment is a combination of objectives between legal and non-legal aspects, which is nothing but the implementation of the values of Pancasila as the source of all laws, and legal ideals to be achieved in the sentencing system or criminal law enforcement system. which is then applied at each stage (pre-adjudication, adjudication, and postadjudication) as a unified sentencing system or criminal law enforcement system. These non-legal aspects become very important to consider and are included in the sentencing guidelines, because the purpose of this punishment is a combination of objectives between legal and non-legal aspects, which is nothing but the implementation of the values of Pancasila as the source of all laws, and legal ideals to be achieved in the sentencing system or criminal law enforcement system.

\section{CONCLUSION}

The non-formulation of the objectives and guidelines for sentencing in the provisions of material law, formal law, and its implementing rules, resulted in normative criminal law enforcement as if it had lost its soul/spirit, and "taste" in carrying out its sentencing system. Therefore, a reconstruction (rearrangement) is needed, and a renewal of the purpose, and guidelines for punishment in the Indonesian national legal system, by adapting it to the development of criminal theory, and the main values of the Indonesian nation contained in Pancasila, as well as strengthening the guarantee of protection HAM. Reconstruction (rearrangement, and renewal) of its conceptions must be carried out by aligning them with the values of Pancasila (as the philosophy of the state, and at the same time as ideals and sources of law/rechsidee), and guaranteeing the 
protection of human rights which ideally is carried out through a renewal of policy formulation (formulation) against the entire Indonesian national legal system, especially as in its material law, to be followed up in formal law, and its criminal implementers.

Whereas in the development of the latest RKUHP, basically it has been regulated and compiled regarding the purpose of punishment, and guidelines for sentencing. However, according to the author, these provisions still have to be studied, and refined so that their application becomes ideal, balanced, and in line with the direction of the goal of punishment which is comprehensively oriented including protection of the perpetrators, victims, families of perpetrators and/or victims, the general public, and the state. / government, by using the idea of balance that is harmonized with the development of the purpose of punishment based on the characteristics of Pancasila values, and guaranteeing the protection of human rights as the main basis for the development of legal characteristics in Indonesia. As for the ideal concept of sentencing guidelines, the aspects that must be considered in this sentencing must consider in a balanced way the legal aspects, and non-legal aspects (philosophical, sociological, psychological, cultural, economic, and the balance of interests for all parties), and must be aimed at in all stages of the sentencing system or criminal law enforcement system (pre-adjudication, adjudication, and post-adjudication).

\section{REFERENCES}

[1] Andi Hamzah, Hukum Pidana Indonesia, Jakarta: Yarsif Watampone, p. 46, 2010

[2] Any Ismayawati, "Pancasila sebagai Dasar Pembangunan Hukum Di Indonesia", Jurnal Pemikiran Hukum dan Hukum Islam, 2018.

[3] Aristo Evandy A. Barlian, dan Barda Nawawi Arief, "Formulasi Ide Permaafan Hakim (Rechterlijk Pardon) dalam Pembaharuan Sistem Pemidanaan Di Indonesia", Semarang, Universitas Diponegoro, Law Reform, Volume 13, Number 1, P.29, 2017.

[4] Dewi. Erna. Hukum Penitensier Dalam Perspektif. Bandar Lampung. Universitas Lampung. 2013

[5] Fais Yonas Bo'a,"Pancasila sebagai Sumber Hukum dalam Sistem Hukum Nasional", Yogyakarta, Universitas Atmajaya,Jurnal Konstitusi, Volume 15, Number 1, p. 1, March 2018

[6] Hamzah, Andi, Sistem Peradilan Pidana di Indonesia, (Jakarta): Sapta Artha Jaya, 1993.

[7] Ismail Rumadan, "Problem Lembaga Pemasyarakatan di Indonesia dan Reorientasi Tujuan Pemidanaan", (Jakarta), Jurnal Hukum dan Peradilan, Volume 2, Number 2 July 2013

[8] Kaelan, 2006, Pancasila as the Basic Orientation for the Development of Legal Studies, Jakarta, p. 6. As quoted in Kuat Puji Prayitno, "Pancasila Sebagai "Screening Board" Dalam Membangun Hukum Di Tengah Arus Globalisasi Dunia Yang Multidimensional", Purwekerto, Universitas
Jenderal Soedirman, Jurnal Dinamika Hukum, Vol. 11 Special Issue February p. 151, 2011.

[9] Maroni, Sopian Sitepu, Nenny Dwi Ariani, "Humanistic Law Enforcement As The Application Of The Value Of Justice, Expediency And Legal Certainty Based On Pancasila", (Bandar Lampung, Universitas Lampung), Journal of Legal, Ethical and Regulatory Issues, Volume 22, Issue 4, 2019.

[10] Muladi, "Proyeksi Hukum Pidana Materiil Indonesia di Masa Datang", (Semarang), Pidato Pengukuhan Guru Besar Ilmu Hukum Pidana, 1990.

[11] Muladi, "Proyeksi Hukum Pidana Materiil Indonesia di Masa Datang", (Semarang), Pidato Pengukuhan Guru Besar Ilmu Hukum Pidana, 1990

[12] Muladi, "Proyeksi Hukum Pidana Materiil Indonesia di Masa Datang", (Semarang), Pidato Pengukuhan Guru Besar Ilmu Hukum Pidana, 1990

[13] Pengkajian Hukum Tentang Penerapan Restorative Justice Dalam Penyelesaian Tindak Pidana yang Dilakukan Oleh Anak-Anak", (Jakarta, Badan Pembinaan Hukum Nasional, 2013), p. 33, 2013.

[14] Petrus Irwan Panjaitan, "Upaya Pembaharuan Pemikiran Dr.Sahardjo Mengenai Pemasyarakatan Sebagai Tujuan Pidana Penjara Untuk Pembentukan KUHP Dimasa Mendatang", (Jakarta: Universitas Indonesia), Postgraduate Law Dissertation, 2004.

[15] Putu Mery Lusyana Dewi, dan I Ketut Rai Setiabudhi, "Kebijakan Formulasi Rechterlijk Pardon (Pemaafan Hakim) dalam RKUHP", (Bali, Fakultas Hukum Universitas Udayana), Jurnal Kertha Wicara Vol. 9 No. 9, pp. 2, 2020.

[16] Republic of Indonesia, Draft Law on the Criminal Code, Article 52 paragraph (1), and (2).

[17] Republic of Indonesia, Draft Law on the Criminal Code, Loc.Cit., Article 53, and Article 54

[18] See Rico Aldiyanto Batuwael, Olga A. Pangkerego, and Anna S. Wahongan, "Fungsi Pidana Denda Dalam Sistem Pemidanaan Di Indonesia", (Manado, FH Unsrat), Lex Crimen Vol. IX/No. 3/Jul-Sep/2020, p. 94.

[19] Sudarto, Pemidanaan, Pidana dan Tindakan, (BPHN, 1982), p. 4., as quoted in the Kementerian Hukum dan Hak Asasi Manusia Republik Indonesia, "Draft Naskah Akademik Rancangan Undang-Undang Tentang Kitab Undang-Undang Hukum Pidana (KUHP)", Loc.Cit., p. 42.

[20] Sunarjo, "Peradilan Sebagai Pilar Negara Hukum Dalam Perspektif Pancasila", (Malang, Universitas Merdeka Malang), Jurnal Cakrawala Hukum, Vol.19, No.1, p. 71-72, June 2014.

[21] Teguh Prasetyo, Hukum Dan Sistem Hukum Berdasarkan Pancasila, Media Perkasa, Yogyakarta, 2013.

[22] Tri Andrisman, Hukum Pidana : Asas-Asas Dan Dasar Aturan Umum Hukum Pidana Di Indonesia, (Bandar Lampung: Universitas Lampung, 2011), p. 30, 2011.

[23] Undang-Undang Tentang Sistem Peradilan Pidana Anak, UU RI Nomor 11 Tahun 2012, Lembaran Negara RI Nomor 153, Tambahan Lembaran Negara RI Nomor 5332, Pasal 1 butir (6), Pasal 5 ayat (1) dan (2).

[24] Utrecht. E., Hukum Pidana I. Bandung. Universitas. 1968. p. 8-

[25] Widya Puspa Rini S., "Pemberian Remisi Terhadap Narapidana Tindak Pidana Korupsi Ditinjau Dari Sistem Pemasyarakatan, (Jakarta: Universitas Indonesia), Postgraduate Thesis of Law, Year, 2012

[26] Yosep Adi Prasetyo, "Hak Ekosob dan Kewajiban Negara", Makalah Komnas HAM, (Jakarta: Komnas Ham), p. 2, 2012. 